\title{
EVALUASI KETAHANAN BERAS LOKAL PROVINSI SUMATERA BARAT TERHADAP HAMA Sitophilus oryzae (L.)
}

\section{EVALUATION RESISTANCE LOCAL RICE OF PROVINCE WEST SUMATRA ON PESTS Sitophilus oryzae (L.)}

\author{
Muhtia Annisa, Hendrival" dan Khaidir \\ Program Studi Agroekoteknologi Fakultas Pertanian, Universitas Malikussaleh, Aceh, Indonesia. \\ *Email: hendrival@unimal.ac.id \\ * Corresponding Author, Diterima: 14 April 2021, Direvisi: 20 Juni 2021, Disetujui: 19 Ags. 2021
}

\begin{abstract}
The selection rice of resistant to pests Sitophilus oryzae can be done through the utilization of local paddy. The study aims to determine the level susceptibility of local Province West Sumatera against pest attack S. oryzae. The experiments were conducted at the Laboratory of Plant Pests and Diseases. The study used a completely randomized design (CRD) with three replications. Types of rice from local paddy of Province West Sumatra include Batang Piaman, Kuriak, Kuku Balam, Ampek Duo Pilihan, Banang Pulau, Batu Sangka, Gandah Kuniang, Geha, and Bareh Solok. The treatment was repeated three times so that there were 27 experimental units. The evaluation of rice resistance using the method without choice. The results showed that rice from local paddy from Province West Sumatera has a level resistance from resistance and moderately to pest infestations S. oryzae. The rice Gandah Kuniang classified in the resistant category, while Batu Sangka, Kuku Balam, Bareh Solok, Batang Piaman, Banang Pulau, Kuriak, Geha, and Ampek Duo Pilihan classified in the moderate category. The susceptibility of local rice was affected by the number of F1 $\left(r=0,975^{* *}, P<0,01\right)$ and median development time $S$. oryzae $(r=-$ $\left.0,969^{* *}, P<0,01\right)$.
\end{abstract}

Keywords: Index susceptibility, Local paddy Province West Sumatra, susceptibility, Sitophilus oryzae.

\begin{abstract}
ABSTRAK
Pemilihan beras yang tahan terhadap hama Sitophilus oryzae dapat dilakukan melalui pemanfaatan padi lokal. Penelitian ini bertujuan untuk mengetahui tingkat kerentanan beras lokal Provinsi Sumatera Barat terhadap serangan hama S. oryzae. Percobaan dilakukan di Laboratorium Hama dan Penyakit Tanaman. Penelitian ini menggunakan Rancangan Acak Lengkap (RAL) dengan tiga ulangan. Jenis beras dari padi lokal Provinsi Sumatera Barat antara lain Batang Piaman, Kuriak, Kuku Balam, Ampek Duo Pilihan, Banang Pulau, Batu Sangka, Gandah Kuniang, Geha, dan Bareh Solok. Perlakuan diulang sebanyak tiga kali sehingga didapatkan 27 satuan percobaan. Evaluasi ketahanan beras menggunakan metode tanpa pilihan. Hasil penelitian menunjukkan bahwa beras dari padi lokal Provinsi Sumatera Barat memiliki tingkat kerentanan resisten dan moderat terhadap serangan hama $S$. oryzae. Beras Gandah Kuniang tergolong dalam kategori resisten, sedangkan Batu Sangka, Kuku Balam, Bareh Solok, Batang Piaman, Banang Pulau, Kuriak, Geha, dan Ampek Duo Pilihan tergolong dalam kategori moderat. Kerentanan beras dipengaruhi oleh jumlah F1 $\left(r=0,975^{* *}, P<0,01\right)$ dan median waktu perkembangan $S$.
\end{abstract}


$\operatorname{oryzae}\left(r=-0,969^{* *}, P<0,01\right)$.

Kata kunci : Indeks kerentanan Kerentanan, Sitophilus oryzae, Padi lokal Provinsi Sumatera Barat

\section{PENDAHULUAN}

Beras merupakan makanan utama bagi penduduk di Indonesia dan sebagai negara dengan jumlah konsumsi beras per kapita tertinggi. Seiring bertambahnya jumlah penduduk maka kebutuhan akan beras juga semakin tinggi, sehingga produksi padi juga harus meningkat setiap tahunnya agar dapat mengimbangi pertambahan jumlah penduduk (Syahrullah et al., 2019). Ketersediaan beras yang melimpah pada saat musim panen padi menyebabkan beras harus disimpan untuk dapat digunakan pada waktu tertentu. Penyimpanan beras bermanfaat untuk menjaga ketersedian pangan terhadap kegagalan panen dan bencana (Hendrival \& Meutia, 2016). Selama proses penyimpanan, beras dapat mengalami penurunan kualitas dan kuantitas yang disebabkan oleh serangan hama pascapanen (Hendrival \& Meutia, 2016; Hendrival \& Melinda, 2017; Hendrival \& Mayasari, 2017). Berbagai jenis serangga hama pascapanen yang menyerang beras di Indonesia yaitu Sitophilus oryzae, S. zeamais, Corcyra cephalonica, Plodia interpunctella, Ephestia elutella, Rhyzopertha dominica, Cryptolestes ferrugineus, Oryzaephilus surinamensis (Kalshoven, 1981; Anggara \& Sudarmaji, 2008; Hendrival et al., 2019). Hama Sitophilus oryzae (Coleoptera: Curculionidae) merupakan hama primer pada komoditas pertanian berupa serealia dan banyak ditemukan di negara-negara Asia (Zunjare et al., 2016). Hama S. oryzae tergolong sebagai serangga polifag yang merusak beras, sorgum, gandum, dan jagung di penyimpanan (Longstaff, 1981) serta menyebabkan kerusakan paling dominan pada beras (Hendrival \& Meutia, 2016; Hendrival \& Melinda, 2017). Kerusakan beras selama penyimpanan meliputi penurunan bobot dan kontaminasi beras dari kotoran serta penurunan kandungan nutrisi beras. Larva dan Imago S. oryzae merusak endosperm beras sehingga mengurangi kandungan karbohidrat, protein dan vitamin (Hendrival et al., 2017). Pengendalian hama S. oryzae dengan insektisida sintetikmelalui fumigasi secara terusmenerus dapat mengakibatkan berbagai dampak negatif seperti toksisitas pada konsumen dan resistensi S. oryzae (Benhalima et al., 2004).

Kerusakan beras selama penyimpanan yang disebabkan oleh $S$. oryzae dapat dikurangi dengan cara menyimpan beras yang memiliki sifat ketahanan terhadap hama tersebut. Hasil penelitian Khan \& Halder (2012) dan Oyegoke et al. (2014) menunjukkan bahwa pengembangan varietas tahan pada padi berperan penting dalam mengurangi kerugian akibat serangan $S$. oryzae selama penyimpanan. Penyimpanan beras yang memiliki ketahanan terhadap S. oryzae sebagai metode pengendalian yang menguntungkan karena ketahanan serealia dapat dipertahankan selama penyimpanan dalam jangka waktu lama meskipun munculnya biotipe dari hama. Dampak negatif dari penggunaan insektisida sintetik selama penyimpanan beras dapat dieliminasi dengan menyimpan beras dari varietas padi yang tidak rentan terhadap S. oryzae. 
Pengembangan ketahanan beras dapat dilakukan dengan pengujian ketahanan beras dari berbagai aksesi padi lokal (Gbaye \& Ajiye, 2016).

Aksesi padi lokal Sumatera Barat masih banyak ditanam oleh petani di berbagai kabupaten di Provinsi Sumatera Barat. Hingga kini, beras lokal Sumatera Barat belueridentifikasi memiliki ketahanan terhadap infestasi S. oryzae. Kajian ketahanan beras lokal terhadap infestasi S. oryzae telah dilaporkan oleh Kamsiati et al. (2013), Rini \& Hendrival (2017), Romadani \& Hendrival (2018), dan Hendrival et al. (2018) di Indonesia. Kajian analisis ketahanan beras dari padi lokal Provinsi Sumatera Barat terhadap $S$. oryzae memberikan informasi yang dapat dijadikan sebagai rekomendasi bagi petani untuk membudidayakan padi lokal yang tahan dan bermanfaat bagi pengembangan varietas unggul padi baru melalui upaya pemuliaan yang memiliki ketahanan terhadap hama tersebut. Penelitian bertujuan mengevaluasi ketahanan beras dari padi lokal Provinsi Sumatera Barat terhadap hama S. oryzae selama penyimpanan.

\section{BAHAN DAN METODE}

Penelitian dilaksanakan di Laboratorium Hama dan Penyakit Tanaman Fakultas Pertanian Universitas
Malikussaleh, Aceh Utara dari bulan Juli sampai Oktober 2020. Sumber beras lokal diperoleh dari petani di Kecamatan Tigo Nagari dan Kecamatan Simpang Alahan Mati, Kabupaten Pasaman Propinsi Sumatera Barat. Pengukuran dimensi beras lokal tersebut berdasarkan Hendrival et al. (2018) yaitu pengukuran panjang butiran beras diantara dua ujung butiran beras utuh, sedangkan lebar butiran beras diantara punggung dan perut beras dari 20 butiran beras yang diambil secara acak. Bentuk beras merupakan rasio panjang dan lebar beras. Pengukuran panjang dan lebar butiran beras menggunakan jangka sorong. Pengelompokan beras berdasarkan ukuran panjang yaitu sangat panjang $(>7,5 \mathrm{~mm})$, panjang $(6,6-7,50$ $\mathrm{mm})$, sedang (5,51-6,60 mm), dan pendek ( $<5,5 \mathrm{~mm})$. Bentuk butiran beras dikelompokkan menjadi ramping $(>3,0)$, sedang $(2,1-3,0)$, agak bulat $(1,1-2,0)$, dan bulat $(<1,1)$ (Indrasari et al., 2008). Hasil pengukuran dimensi beras disajikan pada Tabel 1 .

Pembiakan S. oryzae. Pembiakan S. oryzae dilakukan untuk memperoleh imago $S$. oryzae dalam jumlah yang banyak dan umur yang seragam. Pembiakan S. oryzae berdasarkan metode Hendrival \& Meutia (2016) yaitu imago-imago diinfestasikan ke dalam stoples pemeliharaan dengan tingkat populasi

Tabel 1. Dimensi beras dari padi lokal Provinsi Sumatera Barat

\begin{tabular}{lccc}
\hline \multicolumn{1}{c}{ Jenis beras dari varietas padi lokal } & Panjang $(\mathrm{P})(\mathrm{mm})$ & Lebar $(\mathrm{L})(\mathrm{mm})$ & Bentuk (rasio P/L) \\
\hline Batang Piaman & 7,17 (panjang) & 2,20 & 3,25 (ramping) \\
Banang Pulau & 5,86 (sedang) & 2,13 & 2,76 (sedang) \\
Bareh Solok & 6,25 (sedang) & 2,18 & 2,86 (sedang) \\
Ampek Duo Pilihan & 6,12 (sedang) & 2,28 & 2,68 (sedang) \\
Kuriak & 5,96 (sedang) & 2,12 & 2,81 (sedang) \\
Kuku Balam & 7,56 (sangat panjang) & 2,13 & 3,35 (ramping) \\
Batu Sangka & 6,65 (panjang) & 2,25 & 2,95 (sedang) \\
Gandah Kuniang & 6,33 (sedang) & 2,28 & 2,77 (sedang) \\
Geha & 6,19 (sedang) & 2,22 & 2,78 (sedang) \\
\hline
\end{tabular}


40 pasang imago dengan $250 \mathrm{~g}$ beras merah. Pembiakan dilakukan selama empat minggu sesuai dengan siklus hidupnya dari peletakkan telur hingga keluarnya imago. Media beras tersebut diinkubasikan kembali sampai muncul imago. Pengayakan dilakukan secara berulang setiap hari hingga didapatkan jumlah imago dengan umur yang seragam.

Evaluasi Ketahanan Beras terhadap S. oryzae. Evaluasi ketahanan beras dilakukan dengan metode tanpa pilihan. Setiap jenis beras yang digunakan dalam penelitian sebanyak 1000 butir beras utuh dan dimasukkan ke dalam stoples plastik dengan ukuran tinggi $12 \mathrm{~cm}$ dan diameter $15 \mathrm{~cm}$. Pada tutup stoples plastik diberi lubang aerasi yang dilapisi kain kasa. Imago dari hasil pembiakan diinfestasikan dengan tingkat populasi awal yaitu lima pasang imago ke dalam 1000 butir beras utuh dan disimpan selama dua bulan. Evaluasi ketahanan menggunakanmetode Dobie(1974) yang berdasarkan jumlah F1 dan median waktu perkembangan S. oryzae. Jumlah F1 dihitung setelah beras dan imago $S$. oryzae diinkubasi selama dua minggu sampai seluruh imago F1 telah muncul secara keseluruhan dari setiap beras. Median waktu perkembangan adalah lamanya waktu yang diperlukan hingga munculnya $50 \%$ atau separuh dari populasi awal yang mencapai imago. Penghitungan median waktu perkembangan dilakukan setiap hari sejak periode oviposisi sampai kemunculan 50\% imago baru dari populasi awal. Klasifikasi tingkat kerentanan berdasarkan nilai indeks kerentanan yaitu resisten $(0$ 3), moderat (4-7), rentan (8-10), dan sangat rentan $(>11)$. Indeks kerentanan Dobie dihitung menggunakan rumus berikut.

$$
\text { Indeks kerentanan }=100 \times \frac{\left(\log _{\mathrm{e}} F\right)}{D}
$$

Keterangan:

$\mathrm{F}=$ total jumlah F1 S. oryzae

$\mathrm{D}=$ median waktu perkembangan

Pengukuran Kerusakan Beras. Pengukuran kerudakan beras meliputi persentase kehilangan bobot dan persentase beras berlubang. Pengamatan kerusakan beras dilakukan setelah semua imago F1 muncul. Pemisahan dan penghitungan dilakukan terhadap jumlah beras utuh dan berlubang. Penghitungan persentase kehilangan bobot beras dan beras berlubang menggunakan rumus berikut (Gwinner \& Harnish, 1996).

$$
\begin{aligned}
& K B=\frac{\left(U \times N_{d}\right)-\left(D \times N_{u}\right)}{U\left(N_{d}+N_{u}\right)} \times 100 \% \\
& B B=\frac{N_{d}}{N} \times 100 \%
\end{aligned}
$$

Keterangan:

$\mathrm{KB}=$ kehilangan bobot beras

$\mathrm{BB}=$ beras berlubang

$\mathrm{U}=\operatorname{bobot}$ biji utuh $(\mathrm{g})$

$\mathrm{D}=$ bobotbijiberlubang $(\mathrm{g})$

$\mathrm{N}_{\mathrm{u}}=$ jumlahbiji utuh

$\mathrm{N}_{\mathrm{d}}=$ jumlahbijiberlubang

$\mathrm{N}=$ jumlah biji sampel

Rancangan Penelitian dan Analisis Data. Penelitian disusun dalam Rancangan Acak Lengkap dengan perlakuan jenis beras dari padi lokal Kecamatan Tigo Nagari dan Kecamatan Simpang Alahan Mati, Kabupaten Pasaman Propinsi Sumatera Barat. Data hasil pengamatan dianalisis dengan analisis ragam dan uji Duncan taraf 5\%. Untuk mengukur kekuatan 
hubungan antara jumlah F1 S. oryzae, median waktu perkembangan $S$. oryzae, kerusakan beras terhadap indeks kerentanan beras ditentukan dengan analisis korelasi.

\section{HASIL DAN PEMBAHASAN}

\section{Evaluasi Ketahanan Beras}

Jenis beras Provinsi Sumatera Barat mempengaruhi jumlah F1 S. oryzae $\left(F=188,22^{* *} ; \mathrm{db}\right.$ $=8 ; P<0,0001)$, median waktu perkembangan $(F=$ 5,92**; db=8; dan $P<0,0009)$, dan indeks kerentanan $\left(F=26,49^{* *} ; \mathrm{db}=8 ; P<0,0001\right)$. Jumlah F1 imago S. oryzae paling tinggi dijumpai pada beras Ampek Duo Pilihan mencapai 131 imago/1000 butir beras dan berbeda nyata dengan beras lainnya. sedangkan jumlah F1 paling rendah dijumpai pada beras Gandah Kuniang yaitu $24,67 \mathrm{imago} / 1000$ butir beras dan berbeda nyata dengan jenis beras lainnya. Hasil penelitian menunjukkan beras Ampek Duo Pilihan merupakan jenis makanan yang paling disukai oleh $S$. oryzae dibandingkan dengan jenis beras dari varietas lainnya (Tabel 2 ).
Perbedaan jenis beras dari padi lokal Provinsi Sumatera Barat dapat mempengaruhi pertumbuhan populasi $S$. oryzae. Jumlah F1 S. oryzae yang muncul dipengaruhi oleh kualitas beras seperti sifat-sifat fisiologis dan kimiawi yang dapat mempengaruhi perkembangan larva dan imago seperti kekerasan kulit, amilosa, kadar air biji, warna, dan komposisi nutrisi (Romadani \& Hendrival, 2018). Beras mengandung nutrisi yang disukai oleh $S$. oryzae sehingga memiliki tingkat kesesuaian terhadap reproduksi dan perkembangan S. oryzae dibandingkan pada beras lainnya. Kualitas beras berpengaruh terhadap tingkat oviposisi imago betina $S$. oryzae, semakin banyak ketersediaan makanan yang sesuai dengan pertumbuhan $S$. oryzae maka semakin banyak populasi yang akan muncul (Campbell, 2002). Costa et al. (2016) menyatakan bahwa pengaruh varietas sangat siginifikan dengan jumlah serangga yang muncul dan jumlah biji yang dimakan. Jumlah F1 imago tertinggi terdapat pada beras dari varietas Ampek Duo Pilihan, beras tersebut diduga memiliki kandungan nutrisi yang

Tabel 2. Parameter jumlah F1, median waktu perkembangan, dan indeks kerentanan beras dari varietas padi lokal Provinsi Sumatera Barat terhadap S. oryzae

\begin{tabular}{lcccc}
\hline \multicolumn{1}{c}{$\begin{array}{c}\text { Jenis beras dari } \\
\text { varietas padi lokal }\end{array}$} & $\begin{array}{c}\text { Jumlah F1 } \\
\text { (imago/1000 butir } \\
\text { beras) }\end{array}$ & $\begin{array}{c}\text { Median waktu } \\
\text { perkembangan } \\
\text { (hari) }\end{array}$ & $\begin{array}{c}\text { Indeks } \\
\text { Kerentanan }\end{array}$ & Katagori \\
\hline Batang Piaman & $62,33 \mathrm{~d}$ & $37,67 \mathrm{bc}$ & $4,78 \mathrm{de}$ & Moderat \\
Banang Pulau & $66,33 \mathrm{~d}$ & $35,67 \mathrm{bc}$ & $5,14 \mathrm{dc}$ & Moderat \\
Bareh Solok & $43,67 \mathrm{e}$ & $39,67 \mathrm{~b}$ & $4,15 \mathrm{e}$ & Moderat \\
Ampek Duo Pilihan & $131 \mathrm{a}$ & $31,33 \mathrm{c}$ & $6,78 \mathrm{a}$ & Moderat \\
Kuriak & $94,33 \mathrm{c}$ & $34 \mathrm{bc}$ & $5,81 \mathrm{bc}$ & Moderat \\
Kuku Balam & $60,67 \mathrm{~d}$ & $38,67 \mathrm{~b}$ & $4,64 \mathrm{de}$ & Moderat \\
Batu Sangka & $51,33 \mathrm{e}$ & $39,33 \mathrm{~b}$ & $4,36 \mathrm{e}$ & Moderat \\
Gandah Kuniang & $24,67 \mathrm{f}$ & $48,33 \mathrm{~s}$ & $2,92 \mathrm{f}$ & Resisten \\
Geha & $121,33 \mathrm{~b}$ & $33,33 \mathrm{bc}$ & $6,26 \mathrm{ab}$ & Moderat \\
\hline
\end{tabular}

Keterangan: Angka yang diikuti oleh huruf yang sama pada kolom yang sama tidak berbeda nyata berdasarkan uji DMRT pada taraf 0,05 . 
disukai oleh $S$. oryzae sehingga memiliki tingkat kesesuaian terhadap reproduksi dan perkembangan hama tersebut dibandingkan pada beras lainnya.

Median waktu perkembangan S. oryzae paling lama dijumpai pada beras Gandah Kuniang yaitu 48,33 hari yang berbeda nyata dengan beras dari varietas lainnya, sedangkan median waktu perkembangan paling singkat dijumpai pada beras Ampek Duo Pilihan yaitu 31,33 hari yang berbeda nyata dengan beras dari varietas lainnya (Tabel 2). Periode median perkembangan dari telur sampai menjadi imago $S$. oryzae pada beras lokal Sumatera Barat berkisar antara 31,33 sampai 48,33 hari yang tergolong lama dibandingkan dengan hasil penelitian Romadani \& Hendrival (2018) yaitu 30-35,67 hari. Kisaran median waktu perkembangan $S$. oryzae pada beras lokal Sumatera Barat juga memiliki kesamaan pada beras lokal dataran tinggi di Aceh yaitu 32,67-49 hari (Hendrival et al., 2018). Median waktu perkembangan merupakan parameter untuk menentukan ketahanan beras terhadap S. oryzae. Hendrival et al. (2018) mengemukakan bahwa median waktu perkembangan yang lama dapat menyebabkan beras tersebut resisten terhadap $S$. oryzae selama periode penyimpanan.

Nilai indeks kerentanan berkisar antara 2,92 sampai 6,78. Indeks kerentanan paling rendah dijumpai pada beras Gandah Kuniang sebesar 2,92 dan berbeda nyata dengan jenis beras lainnya, sedangkan nilai indeks kerentanan paling tinggi dijumpai pada beras Ampek Duo Pilihan sebesar 6,78 dan tidak berbeda nyata dengan beras Geha. Berdasarkan nilai indeks kerentanan diketahui bahwa beras Gandah Kuniang tergolong resisten, sedangkan beras Batang Piaman,
Kuriak, Kuku Balam, Ampek Duo Pilihan, Banang Pulau, Batu Sangka, Geha, dan Bareh Solok tergolong moderat terhadap serangan hama $S$. oryzae selama penyimpanan beras (Tabel2). Nilai indeks kerentanan merupakan parameter untuk menentukan ketahanan beras terhadap $S$. oryzae. Nilai indeks kerentanan yang tinggi menggambarkan beras tersebut rentan, sedangkan nilai indeks kerentanan yang rendah maka beras tersebut resisten terhadap S. oryzae (Hendrival et al., 2018).

Hasil analisis korelasi menunjukkan bahwa kerentanan beras dipengaruhi oleh jumlah F1 ( $r=$ $\left.0,975^{* *}, P<0,01\right)$ dan median waktu perkembangan S. oryzae $\left(r=-0,969^{* *}, P<0,01\right)($ Tabel 3). Korelasi antar karakter ini menunjukkan bahwa Kerentanan beras ditentukan oleh banyaknyajumlah F1 dan median waktu perkembangan yang singkat. Hasil penelitian Rini \& Hendrival (2017), Romadani \& Hendrival (2018), dan Hendrival et al. (2018) menunjukkan bahwa kerentanan beras lokal ditentukan oleh jumlah F1 yang muncul dan median waktu perkembangan $S$. oryzae pada beras tersebut. Jumlah F1 S. oryzae yang banyak dan median waktu perkembangan yang singkat menyebabkan beras menjadi rentan terhadap $S$. oryzae. Hasil penelitian Hendrival \& Mayasari (2017) juga mengemukakan bahwa kerentanan beras terhadap S. zeamais terhadap ditentukan oleh jumlah F1 yang banyak dan median waktu perkembangan yang singkat. Goftishu \& Belete (2014) yang menyatakan bahwa varietas sorgum dengan tingkat kerentanan yang tinggi memiliki periode median waktu perkembangan $S$. oryzae yang lebih cepat sedangkan varietas dengan tingkat kerentanan yang rendah memiliki periode median waktu perkembangan S. oryzae yang lebih 
lama. Hasil yang sama juga dikemukakan oleh Soujanya et al. (2016), terdapat korelasi positif sangat signifikan antara jumlah F1 S. oryzae pada jagung dengan nilai indeks kerentanan dan korelasi negatif sangat signifikan antara nilai indeks kerentanan dengan median waktu perkembangan.

Hasil analisis ragam menunjukkan bahwa jenis beras asal Provinsi Sumatera Barat berpengaruh sangat nyata terhadap persentase kehilangan bobot $(F=$ $89,50 ; \mathrm{db}=8 ; P<0,0001)$ dan persentase beras berlubang $(F=159,61 ; \mathrm{db}=8 ; P<0,0001)$. Hasil penelitian menunjukkan bahwa serangan $S$. oryzae mempengaruhi persentase kehilangan bobot dan persentase beras berlubang. Persentase kehilangan bobot paling tinggi terdapat pada beras Ampek Duo Pilihan sebesar $14,67 \%$ dan tidak berbeda nyata dengan beras Geha tetapi berbeda nyata dengan beras lainnya, sedangkan paling rendah terdapat pada beras Gandah Kuning sebesar 5\% yang berbeda nyata dengan beras lainnya. Persentase beras berlubang paling tinggi dijumpai pada beras Ampek Duo Pilihan sebesar $18,97 \%$ dan berbeda nyata dibandingkan dengan beras lainnya. Persentase beras berlubang paling rendah dijumpai pada beras Gandah Kuniang sebesar $6,63 \%$ yang berbeda nyata dengan beras lainnya (Tabel 3). Kerusakan beras berkaitan dengan aktivitas makan dari larva dan imago dengan gejala kerusakan seperti terdapat lubang gerekan dan beras menjadi berlubang. Pembentukan bubuk dari beras yang rusak dan tidak layak dikonsumsi.

Kerusakan beras dapat mempengaruhi kerentanannya, beras dengan kerusakan yang tinggi tergolong rentan terhadap S. oryzae. Hasil analisis korelasi menunjukkan bahwa terdapat korelasi positif sangat nyata antara persentase kehilangan bobot $(r=$ $\left.0,988^{* *}, P<0,01\right)$ dan persentase beras berlubang $(r=$ $0,979^{* *}, P<0,01$ ) dengan kerentanan beras (Tabel 3). Korelasi antar karakter ini menunjukkan bahwa kerusakan pada beras lokal Sumatera Barat yang rendah menyebabkan beras tergolong resisten dan moderat. Hasil penelitian yang sama juga dilaporkan oleh Kamsiati et al. (2013) bahwa kelompok varietas padi lokal Kalimantan Tengah yang resisten memiliki persentase susut bobot beras dan beras berlubang yang rendah, sedangkan varietas yang rentan memiliki persentase susut bobot dan biji berlubang yang tinggi

Tabel 3. Parameter persentase kehilangan bobot dan persentase beras berlubang dari varietas padi lokal Provinsi Sumatera Barat.

\begin{tabular}{lcc}
\hline \multicolumn{1}{c}{ Jenis beras dari varietas padi lokal } & Persentase kehilangan bobot & Persentase beras berlubang \\
\hline Batang Piaman & $10,54 \mathrm{c}$ & $13.26 \mathrm{e}$ \\
Banang Pulau & $12 \mathrm{~b}$ & $14,53 \mathrm{~d}$ \\
Bareh Solok & $8,68 \mathrm{~d}$ & $11,49 \mathrm{f}$ \\
Ampek Duo Pilihan & $14,67 \mathrm{a}$ & $18,97 \mathrm{a}$ \\
Kuriak & $12,27 \mathrm{~b}$ & $15,49 \mathrm{c}$ \\
Kuku Balam & $9,53 \mathrm{~d}$ & $11,73 \mathrm{f}$ \\
Batu Sangka & $9,34 \mathrm{~d}$ & $10,41 \mathrm{~g}$ \\
Gandah Kuniang & $5 \mathrm{e}$ & $6,63 \mathrm{~h}$ \\
Geha & $13,98 \mathrm{a}$ & $17,79 \mathrm{~b}$ \\
\hline
\end{tabular}

Keterangan: Angka yang diikuti oleh huruf yang sama tidak berbeda nyata berdasarkan uji DMRT pada taraf 0,05 
Tabel 4. Matriks korelasi antara median waktu perkembangan, jumlah F1, persentase kehilangan bobot, persentase beras berlubang, dan indeks kerentanan beras dari varietas padi lokal Provinsi Sumatera Barat.

\begin{tabular}{|c|c|c|c|c|c|}
\hline Karakter & $\begin{array}{l}\text { Median waktu } \\
\text { perkembangan }\end{array}$ & Jumlah F1 & $\begin{array}{l}\text { Persentase } \\
\text { kehilangan bobot }\end{array}$ & $\begin{array}{l}\text { Persentase beras } \\
\text { berlubang }\end{array}$ & $\begin{array}{l}\text { Indeks } \\
\text { kerentanan }\end{array}$ \\
\hline $\begin{array}{l}\text { Median waktu } \\
\text { perkembangan }\end{array}$ & 1 & & & & \\
\hline Jumlah F1 & $-0,894^{* *}$ & 1 & & & \\
\hline $\begin{array}{l}\text { Persentase kehilangan } \\
\text { bobot }\end{array}$ & $-0,947^{* *}$ & $0,971^{* *}$ & 1 & & \\
\hline $\begin{array}{l}\text { Persentase beras } \\
\text { berlubang }\end{array}$ & $-0,923^{* *}$ & $0,978^{* *}$ & $0,990^{* *}$ & 1 & \\
\hline Indeks kerentanan & $-0,969^{* *}$ & $0,975^{* *}$ & $0,988^{* *}$ & $0,979^{* *}$ & 1 \\
\hline
\end{tabular}

Keterangan: ** berkorelasi sangat nyata $(P<0,01)$ dan * berkorelasi nyata $(P<0,05)$.

terhadap infestasi $S$. oryzae selama penyimpanan. Kerusakan beras selama penyimpanan juga dipengaruhi oleh jumlah F1 terhadap persentase kehilangan bobot beras $\left(r=0,851^{* *}, P<0,01\right)$ dan persentase sorgum berlubang ( $\left.r=0,967^{* *}, P<0,01\right)$ (Tabel 4). Hasil penelitian Hendrival et al. (2018) menunjukkan bahwa jumlah F1 S. oryzae yang muncul dapat mempengaruhi persentase kerusakan dan penurunan berat yang berkorelasi positif dengan indeks kerentanan. Semua jenis beras dari padi lokal Sumatera Barat tergolong resisten dan moderat sehingga memiliki peran penting dalam meminimalkan kerugian selama penyimpanan beras di daerah Sumatera Barat.

\section{KESIMPULAN}

Beras dari padi lokal Provinsi Sumatera Barat memiliki tergolong resisten dan moderat terhadap $S$. oryzae. Beras Gandah Kuniang tergolong resisten, sedangkan beras Batang Piaman, Kuriak, Kuku Balam, Ampek Duo Pilihan, Banang Pulau, Batu Sangka, Geha, dan Bareh Solok tergolong katagori moderat serta beras Gandah Kuniang yang resisten terhadap hama $S$. oryzae selama penyimpanan dapat direkomendasikan kepada petani untuk lebih banyak membudidayakan padi lokal tersebut.

\section{DAFTAR PUSTAKA}

Anggara, A.W. \& Sudarmaji. 2008. Hama pascapanen padi dan pengendaliannya. Dalam: AA. Darajat, A. Setyono, A.K. Makarim, \& A. Hasanuddin (Editor). Padi: Inovasi Teknologi Produksi. Balai BesarPenelitian Tanaman Padi. Jakarta. LIPI Press. Hlm. 441-472.

Benhalima, H., M.Q. Chaudhry, K.A. Mills, \& N.R. Price. 2004. Phosphine resistance in storedproduct insects collected from various grain storage facilities in Morocco. Journal of Stored Products Research. 40: 241-249.

Campbell, J.F. 2002. Influence of seed rice on exploitation by rice weevil Sitophilus zeamais. Journal of Insect Behavior. 15(3): 429-445.

Costa, D.C.S., A.C.S. Almeida, M.S. Araujo, E.A. Heinrichs, M.C. Lacerda, J.A.F. Barrigossi, \& F.G. Jesus. 2016. Resistance of rice varieties to Sitophilus oryzae (Coleoptera: Curculionidae). Journal Florida Entomologist. 99(4): 769--773. 
Dobie, P. 1974. The Laboratory assessment of the inherent susceptibility of maize varieties to post harvest infestation by Sitophilus zeamais Motsch Coleoptera: Curculionidae) infesting field corn. Journal of Entomology Science. 2(1): 367-375.

Gbaye, O.A. \& O.B. Ajiye. 2016. Susceptibility level of some Nigerian hybrid and local rice varieties to Sitophilus oryzae L. (Coleoptera: Curculionidae). International Journal of Entomology Research. 1(2): 10-13.

Goftishu, M \& K. Belete. 2014. Susceptibility of sorghum varieties to the maize weevil Sitophilus zeamais Motschulsky (Coleoptera: Curculionidae). Agricultural Science Research Journal. 4(5): 95-103.

Gwinner, J.R. \& M.O. Harnish. 1996. Manual on the Prevention of Post Harvest Grain Loss. GTZ, Eschborn.

Hendrival \& R. Meutia. 2016. Pengaruh periode penyimpanan beras terhadap pertumbuhan populasi Sitophilus oryzae (L.) dan kerusakan beras. Biogenesis. 4(2): 95-101.

Hendrival \& L. Melinda. 2017. Pengaruh kepadatan populasi Sitophilus oryzae (L.) terhadap pertumbuhan populasi dan kerusakan beras. Biospecies. 10(1): 17-24.

Hendrival, M.S. Ningsih, Chodiron, \& A. Wismawati. 2017. Toksisitas insektisida nabati dari Famili Asteraceae, Anacardiaceae, dan Euphorbiaceae terhadap Sitophilus oryzae. (Coleoptera: Curculionidae). Jurnal Biosains. 3(1): 1-8.

Hendrival \& E. Mayasari. 2017. Kerentanan dan kerusakan beras terhadap serangan hama pascapanen Sitophilus zeamais L. (Coleoptera: Curculionidae). Jurnal Agro. 4(2): 68-79.

Hendrival, Khaidir, A. Afzal, \& Rahmaniah. 2018. Kerentanan beras asal padi lokal dataran tinggi Aceh terhadap hama pascapanen Sitophilus oryzae L. (Coleoptera: Curculionidae). Jurnal Agroteknologi. 8(2): 21-30.

Hendrival, D. Afriani, \& D.S. Aryani. 2019. Susceptibility and damage cereals to infestation Rhyzopertha dominica (F.) (Coleoptera: Bostrichidae) in storage. Jurnal Agro. 6(1): 57-65.

Indrasari, S.D., E.Y. Purwani, S. Widowati, \& D.S. Damardjati. 2008. Peningkatan nilai tambah beras melalui mutu fisik, cita rasa, dan gizi. Dalam: AA. Darajat, A. Setyono, A.K. Makarim, \& A. Hasanuddin (Editor). Padi: Inovasi Teknologi Produksi. Balai Besar Penelitian Tanaman Padi. Jakarta. LIPI Press. Hlm. 565-590.

Kalshoven, L.G.E. 1981. Pests of Crops in Indonesia. PT. Ichtiar Baru-van Hoeve. Jakarta.

Kamsiati, E., E. Darmawati, \& Y. Haryadi. 2013. Screening varietas padi lokal Kalimantan Tengah terhadap serangan Sitophilus oryzae selama penyimpanan. Pangan. 22(2): 345 356.

Khan, H.R. \& P.K. Halder. 2012. Susceptibility of six varieties of rice to the infestation of rice weevil, Sitophilus oryzae (L.) (Coleoptera: Curculionidae). Dhaka University Journal Biology Science. 21(2): 163-168.

Longstaff, B.C. 1981. Biology of the grain pest species of the genus Sitophilus (Coleoptera: 
Curculionidae): a critical review. Protection Ecology. 2: 82-130.

Oyegoke, O.O., S.O. Babarinde, A.J. Akintola, \& O. Salaudeen. 2014. Susceptibilty of upland and lowland rice varieties to the infestation of rice weevil, Sitophilus oryzae (L.) (Coleoptera: Curculionidae). International Journal of Zoology and Research. 4(5): 19-26.

Rini, S.F. \& Hendrival. 2017. Kajian kerentanan beras dari padi gogo lokal Jambi terhadap Sitophilus oryzae L. (Coleoptera: Curculionidae). Jurnal biogenesis. 5(1): 14-18.

Romadani, F.P. \& Hendrival. 2018. Kajian kerentanan dan kerusakan beras lokal Provinsi Sumatera Selatan terhadap hama pascapanen Sitophilus oryzae L. (Coleoptera: Curculionidae). Jurnal Biota. 4(2): 90-97.
Soujanya, P.L., J.C. Sekhar, C.G. Karjagi, D. Paul, \& P. Kumar. 2016. Evaluation of biophysical, anatomical and biochemical traits of resistance to Sitophilus oryzae L (Coleoptera: Curculionidae) in stored maize. Maydica. 61: 1-8.

Syahrullah, L. Aphrodyanti, \& Mariana. 2019. Kerusakan beras oleh Sitophilus oryzae L. dari beberapa varietas padi. Proteksi Tanaman Tropika. 2(3): 137-141.

Zunjare, R., F. Hossain, V. Muthusamy, S.K. Jha, P. Kumar, J.C. Sekhar, N. Thirunavukkarasu, \& H.S. Gupta. 2016. Genetic variability among exotic and indigenous maize inbreds for resistance to stored grain weevil (Sitophilus oryzae L.) infestation. Cogent Food and Agriculture. 2: 1-10. 